\title{
Pesticides in Norwegian Landfill Leachates
}

\author{
K. Haarstad* and T. Mæhlum
}

Bioforsk Soil and Environment, Department of Ecological Engineering, Ås, Norway

\begin{abstract}
Pesticides have been analyzed in 28 grab samples of untreated and 12 samples of treated leachate from eight Norwegian municipal solid waste (MSW) landfills, over a period of 10 years, with the purpose to screen for compounds and to evaluate the removal in different treatment systems. Also 1 grab samples of leachate sediments is included. A total of 12 compounds were detected. The most frequently detected group of compounds are the phenoxy acids, and they also occur in highest concentrations, up to $230 \mu \mathrm{g} / \mathrm{l}$ for mecoprop, in this study. Also three fungicides and one insecticide were detected, but in much lower concentrations. All samples exceeded the maximum limit value (MLV) for the sum concentration of pesticides in drinking water $(0.5 \mu \mathrm{g} / \mathrm{l})$, and six compounds exceeded the environmental toxicity limit (ETL). Reverse osmosis showed good removal of phenoxy acids, while sequential batch reactor aerobic treatment, as well as aerated lagoons in combination with wetlands, groundwater infiltration and reactor treatment showed slightly lower removal.
\end{abstract}

Key Words: Municipal solid waste (MSW) landfills, leachate, pesticides.

\section{INTRODUCTION}

Pesticides are widely used both in agriculture and forestry, and in other plant productions such as in greenhouses and gardens, and in maintaining roads, railroads and other open areas, the usage on arable land varying from $<1 \mathrm{~kg} / \mathrm{ha}$ to $14 \mathrm{~kg} / \mathrm{ha}$ [1]. Spain has approved more than $500 \mathrm{com}$ pounds, the average in the EU countries being 300, while Norway has presently only about 100 approved compounds. The handling and usage of large quantities of chemicals have a potential to create an important waste fractions going to landfills. The annual sale of active ingredients in Norway was ca. $750 \mathrm{t}$ in 2007 , with a total agricultural area of ca. 10 $000 \mathrm{~km}^{2}$. Pesticides are labelled as hazardous waste and are not allowed to be disposed off at ordinary landfills.

Environmental monitoring of pesticides in surface waters in agricultural areas in Norway showed the detection of 45 compounds including primary metabolites, of which 22 were herbicides, 13 fungicides and 10 insecticides [2]. Maximum concentration was $68 \mu \mathrm{g} / \mathrm{l}$. The most frequently found compounds were bentazone and mecoprop. In ground water 24 compounds were detected in 450 samples collected over 10 years. The most frequent compounds were herbicides, found in $75 \%$ of the samples, followed by fungicides found in $20 \%$ of the samples [3].

There are limited reports on the concentrations of pesticides in MSW leachate. A review [4] of pesticides in leachates listed 24 compounds, including 3 metabolites, found in concentrations ranging from 0.025 to $26 \mu \mathrm{g} / \mathrm{l}$ (chlorprofam), most of the findings were however from one sampling [5]. Another study found phenoxy acids in concentrations up to $65 \mu \mathrm{g} / \mathrm{l}$ in leachate contaminated ground water [6]. A report showed the occurrence of mecoprop and isoproturon in UK leachates, of which the former was readily removed by aerobical treatment [7]. According to regulations and guidelines

Address correspondence to this author at the Bioforsk Soil and Environment: F. A. Dahls vei 20, N-1432 Ås, Norway; Tel: + 47 92846290; Fax: + 476300 9410; E-mail: ketil.haarstad@bioforsk.no on leachate monitoring, phenoxy acids and chlorinated obsolete pesticides such as DDT, lindane and endosulfan, should be analysed every fifth year [8].

Landfill leachate contains high concentrations of suspended and soluble organic matter and thus has a potential of transporting relatively large amounts of hydrophobic compounds. Leachate is generally highly anaerobic and methanogenic with a high $\mathrm{pH}$, or acidic and low in $\mathrm{pH}$, if the waste is fresh, or a combination of these. Pesticides that are resisting anaerobic degradation and have a high water solubility and a low partition coefficient, $\mathrm{pK}_{\mathrm{a}}<7$ are expected to be more readily leached from the waste. The pesticides that are relevant in our study, defined as detected in the untreated samples, have varying water solubility, and six of them are registered as stable under anaerobic conditions, see Table $\mathbf{1 .}$ Herbicides generally have a high solubility, in the order of several hundreds or thousands $\mathrm{mg} / \mathrm{l}$, fungicides have intermediate solubilities with a few $\mu \mathrm{g} / \mathrm{l}$, while insecticides are usually non-soluble in water $<<1 \mu \mathrm{g} / \mathrm{l}$. The solubility is, however, depending on factors such as the content of dissolved organic carbon, e.g. for DDT [9]. The ecotoxicity of the pesticides are usually inversely related to their solubility, and the solubility is much greater than the ecotoxicological limit value.

Here we report the results from screening for pesticides in leachate from seven selected Norwegian MSW landfills, including both closed and operational locations. The sampling was conducted as grab sampling during the period 1997-2007, both before and after treatment of the leachate, in order to evaluate the environmental relevance of the leaking of pesticides from landfilled waste.

\section{MATERIALS AND METHODS}

\section{Locations}

The sampled landfills have mainly received municipal solid waste (MSW) landfills, in addition to limited amounts of other waste fractions such as incinerator ashes, different 
Table 1. Chemical and Toxicological Characteristics of the Detected Pesticides*

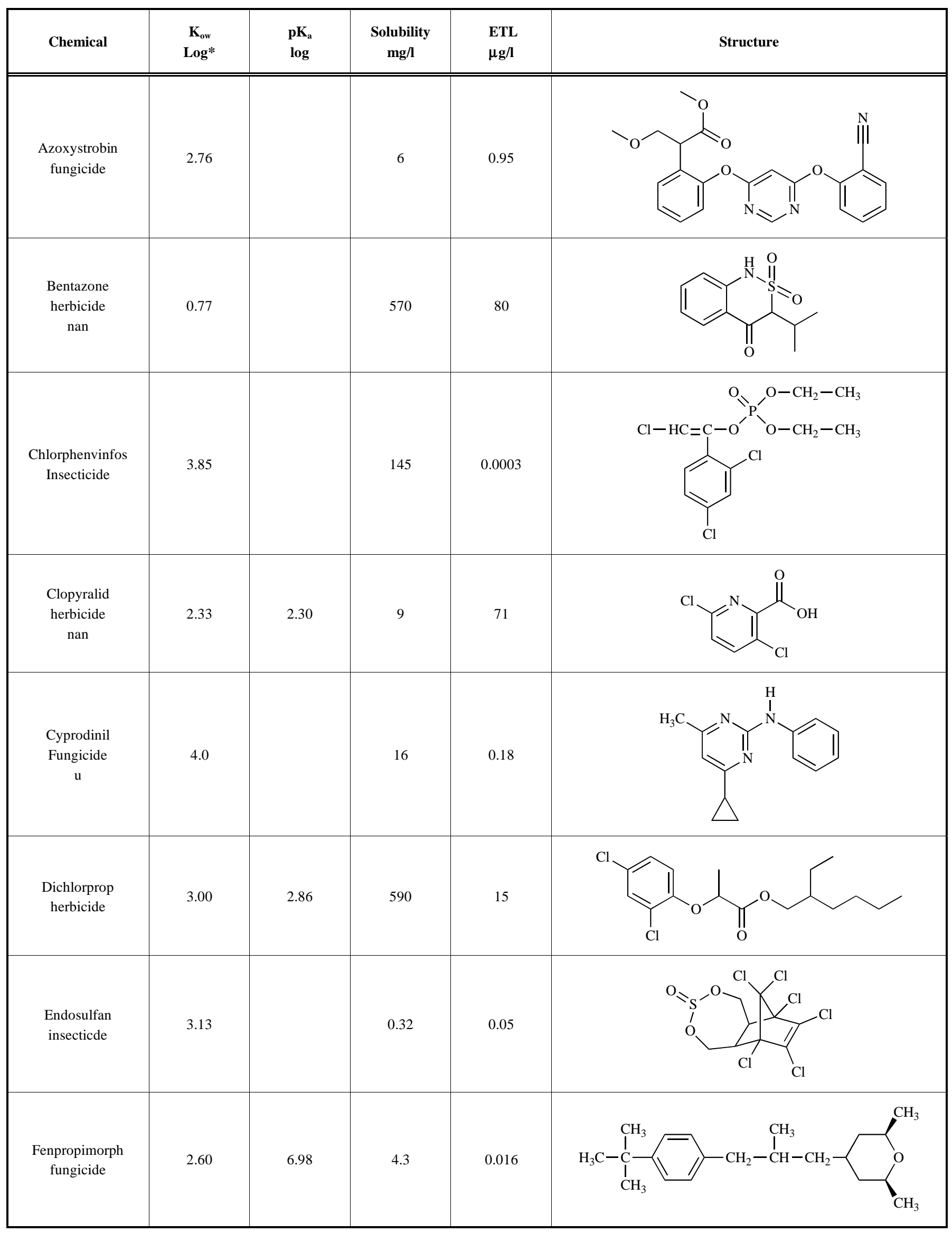


(Table 1) contd...

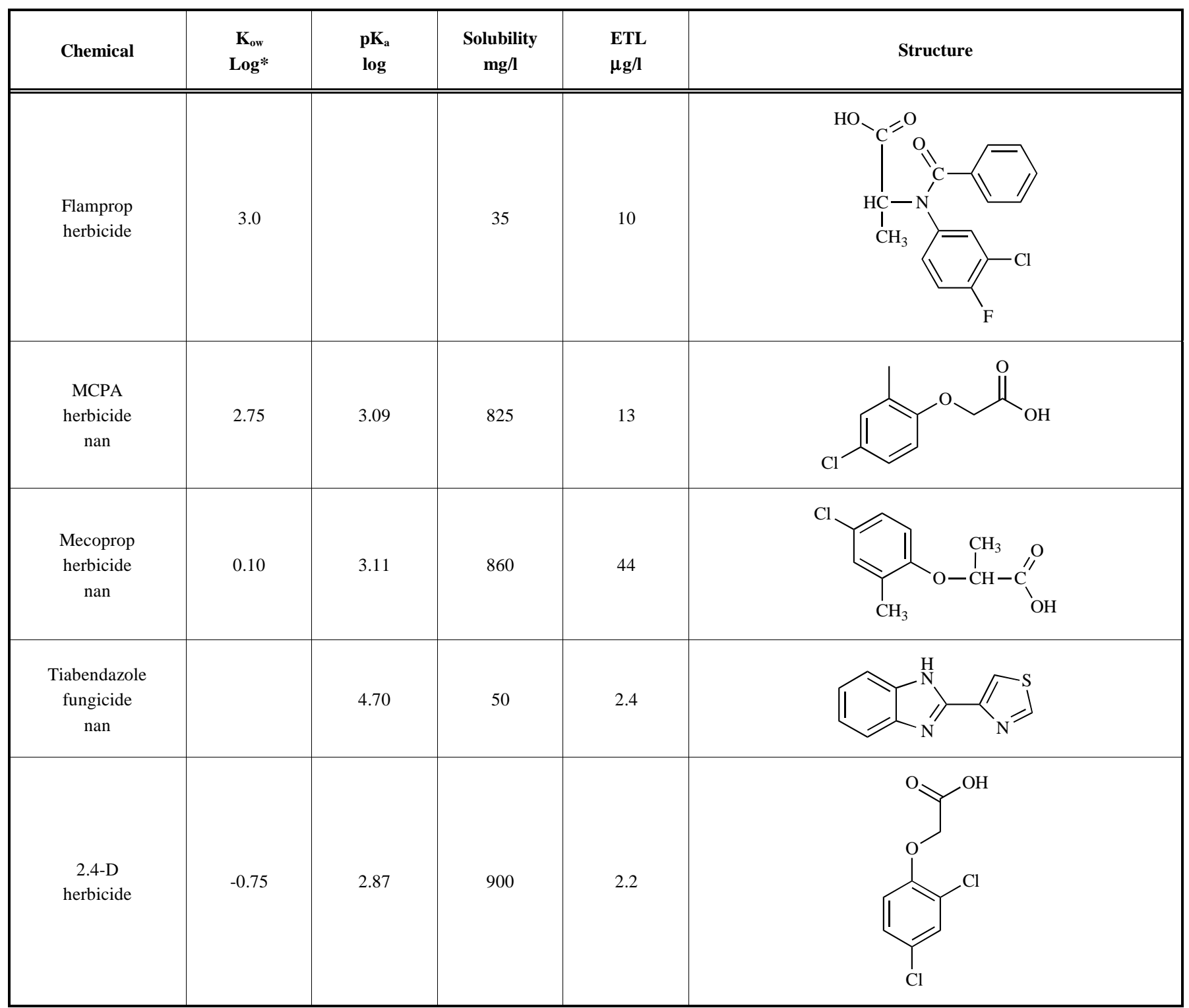

* References: [15-17]. Sol.=water solubility $($ at $\mathrm{pH}=7$ ). ETL=environmental toxicity limit [18]. Nan= anaerobically stable. $\mathrm{u}=$ anaerobically unstable in the presence of $\mathrm{Fe}^{2+}$.

type of industrial wastes, compost and septic sludge. The landfills are described in Table 2 , and typical values of the leachate in Table 3. Two of the landfills were closed in the mid-90's, the others are operational. Their sizes vary from small to large, with about $100000 \mathrm{t}$ to almost 18 million $\mathrm{t}$ of waste. Also the leachates varies in average concentrations, being typically quite diluted in Norway, with an organic content represented by COD values from ca. $150 \mathrm{mg} / \mathrm{l}$ to 5000 $\mathrm{mg} / \mathrm{l}$, and nitrogen from ca. $50 \mathrm{mg} / \mathrm{l}$ to $1100 \mathrm{mg} / \mathrm{l}$. The maximum concentration of organic pollutants varies from 15 $\mu \mathrm{g} / \mathrm{l}$ to $1100 \mu \mathrm{g} / \mathrm{l}$, typically represented by BTEX, phenols and hydrocarbons.

\section{SAMPLING AND ANALYSES}

Four of the landfills have been sampled 5 to 8 times, and four have only been sampled once. Some of the samples are collected in pumping chambers and collection ponds, others are groundwater sampled from wells. At Landfill 3, Spill- haug, the raw leachate samples are collected from a ground water wells just in front of the landfill. The well consists of a polyvinylchloride (PVC) tube screened below the groundwater level. The samples are grab samples collected directly into dark borosilicate bottles, filled completely and kept dark and at $4{ }^{\circ} \mathrm{C}$ until analysis. They have been analysed according to two multimethods M60 and M15, using GC/MS or HPLC/GC-MS [10]. The number of compounds included in the analyses is 65 pesticides including some primary metabolites.

\section{RESULTS}

Pesticides have been analysed in 28 grab samples of untreated leachate from 8 Norwegian municipal solid waste (MSW) landfills, and 12 grab samples from treated leachate, over a period of 10 years, with the purpose to screen for compounds and to evaluate the removal in and emission from different locations and leachate treatment systems. A 
Table 2. Description of Sampled Landfills*

\begin{tabular}{|c|c|c|c|c|c|c|c|}
\hline LF & Name & Treatment & North & East & Total Waste & Surface $^{2}$ & Opened-Closed $^{2}$ \\
\hline \hline 1 & Bølstad & Aerated lagoon & 594525 & 103820 & $200000 \mathrm{~m}^{3}$ & 45000 & $1962-1997$ \\
\hline 2 & Esval & Aerated lagoon+membrane filtration & 601122 & 112329 & $18000000 \mathrm{t}$ & 180000 & $1962-$ \\
\hline 3 & Spillhaug & Natural attenuation+aerated lagoon+CW & 593724 & 112023 & $150000 \mathrm{~m}^{3}$ & 80000 & $1973-$ \\
\hline 4 & Teigen & Aerated lagoon+biodam+CW & 594525 & 103820 & $180000 \mathrm{~m}^{3}$ & 36000 & $1971-1995$ \\
\hline 5 & Bøler & SBR+ STP & 602017 & 110424 & $110424 \mathrm{t}$ & 90000 & $1991-$ \\
\hline 6 & Toraneset & To sea & 593120 & 53256 & $270000 \mathrm{t}$ & 40000 & $1982-$ \\
\hline 7 & Svartasmoget & To sea & 592610 & 51414 & $211000 \mathrm{t}$ & 75000 & $1998-$ \\
\hline 8 & HRA & Areated lagoon & 601400 & 102040 & $736000 \mathrm{t}$ & 80000 & $1970-$ \\
\hline
\end{tabular}

*LF=landfill no. Aerated lagoon=shallow pond with long hydraulic retention time and forced aeration. Membrane filtration=reverse osmosis. Natural attenuation=infiltration to ground water aquifer. $\mathrm{CW}=$ constructed wetland with and without artificial filter layers. SBR=sequential batch reactor with aerobic treatment. STP=sewage treatment plant, natural attenuation=infiltrated to groundwater. Location in latitude and longitude.

Table 3. Typical Values of the Investigated Leachates*

\begin{tabular}{|c|c|c|c|c|c|c|c|c|}
\hline Landfill & $\begin{array}{c}\text { Volume } \\
\mathbf{m}^{3} / \mathbf{y r}\end{array}$ & pH & $\begin{array}{c}\mathrm{EC} \\
\mathrm{mS} / \mathrm{m}\end{array}$ & $\begin{array}{l}\text { COD } \\
\mathrm{mg} / \mathrm{l}\end{array}$ & $\begin{array}{c}\mathrm{SS} \\
\mathrm{mg} / \mathrm{l}\end{array}$ & $\begin{array}{c}\text { Tot-N } \\
\text { mg/l }\end{array}$ & $\begin{array}{c}\mathrm{Fe} \\
\mathrm{mg} / \mathrm{l}\end{array}$ & $\begin{array}{c}\text { Max. C organic pollutants } \\
\mu \mathrm{g} / \mathrm{l}\end{array}$ \\
\hline 1 & 31000 & 7.8 & 166 & 153 & 220 & 68 & 7.4 & 960 (hydrocarbon) \\
\hline 2 & 50000 & 7.3 & 523 & 1688 & 403 & 210 & 37 & 599 (phenol) \\
\hline 3 & 58000 & $6.5-6.9$ & 530 & 510 & & 175 & 23 & $15(\mathrm{PAH})$ \\
\hline 5 & 75000 & 6.8 & 192 & 300 & & 87 & 55 & 71 (BTEX) \\
\hline \multicolumn{9}{|l|}{6} \\
\hline 7 & 193000 & 6,6 & 300 & & & & 25 & 575 (phenol) \\
\hline 8 & 4600 & 7.3 & 1400 & 2500 & 38 & 1100 & 86 & 1100 (BTEX) \\
\hline
\end{tabular}

* EC=electrical conductivity, $\mathrm{COD}=$ chemical oxygen consumption, $\mathrm{SS}=$ suspended solids, Max $\mathrm{C}=$ highest concentration measured of organic pollutants, $\mathrm{HC}=$ hydrocarbons, $\mathrm{PH}=$ phenols, $\mathrm{PAH}=$ polycyclic aromatic hydrocarbons, BTEX=aromatic hydrocarbons. Norway = summary data from Norway (Haarstad et al., 2003).

total of 12 compounds were detected in the untreated leachate, and 9 in the treated leachate. The most frequently detected compounds are the phenoxyacids, and they also occur in highest concentrations, up to $230 \mu \mathrm{g} / \mathrm{l}$ for mecoprop in this study (Table 4, Fig. 1). Also three fungicides and one insecticide were detected, but in much lower concentrations. All samples exceeded the maximum limit value (MLV) for drinking water $(0.5 \mu \mathrm{g} / \mathrm{l}$ for total pesticides), and 6 compounds, the insecticide chlorphenvinphos, the fungicides cyprodinil and Fenpropimorph, and the herbicides 2,4-D, Dichlorprop, and mecoprop, exceeded the environmental toxicity limit (ETL), see Table 1. The compounds found in treated leachate are given in Fig. (2). Chlorphenvinphos and mecoprop exceeded the ETL in treated leachate at location 4.

Fig. (1) shows that the concentrations vary both over time, and both between and within the compounds.

The mean removal varied from $40 \%$ to nearly $100 \%$, see Fig. (2). Reverse osmosis showed good removal of phenoxy acids, while wetlands, groundwater infiltration and reactor treatment showed more variable removal of these compounds (Table 5). The aeration/wetland systems also showed more compounds in the treated leachate. The concentration levels in the outlet from the wetlands coincide with those found in previous studies from agricultural areas [11-14].

\section{CONCLUSIONS}

Pesticides are prevalent in leachate from municipal solid waste landfills in Norway, sometimes at high concentrations. A total of 12 compounds were detected. The most frequently detected group of compounds are the phenoxy acids, and they also occur in highest concentrations. All samples exceeded the maximum limit value (MLV) for the sum concentration of pesticides in drinking water, and six compounds exceeded the environmental toxicity limit (ETL). Reverse osmosis showed good removal of phenoxy acids, while sequential batch reactor aerobic treatment, as well as aerated lagoons in combination with wetlands, groundwater infiltra- 
12 The Open Environmental \& Biological Monitoring Journal, 2008, Volume 1

Table 4. Mean Concentrations $(\mu \mathrm{g} / \mathrm{l})$ in Untreated Leachate from Norwegian Landfills (LF 1-8)

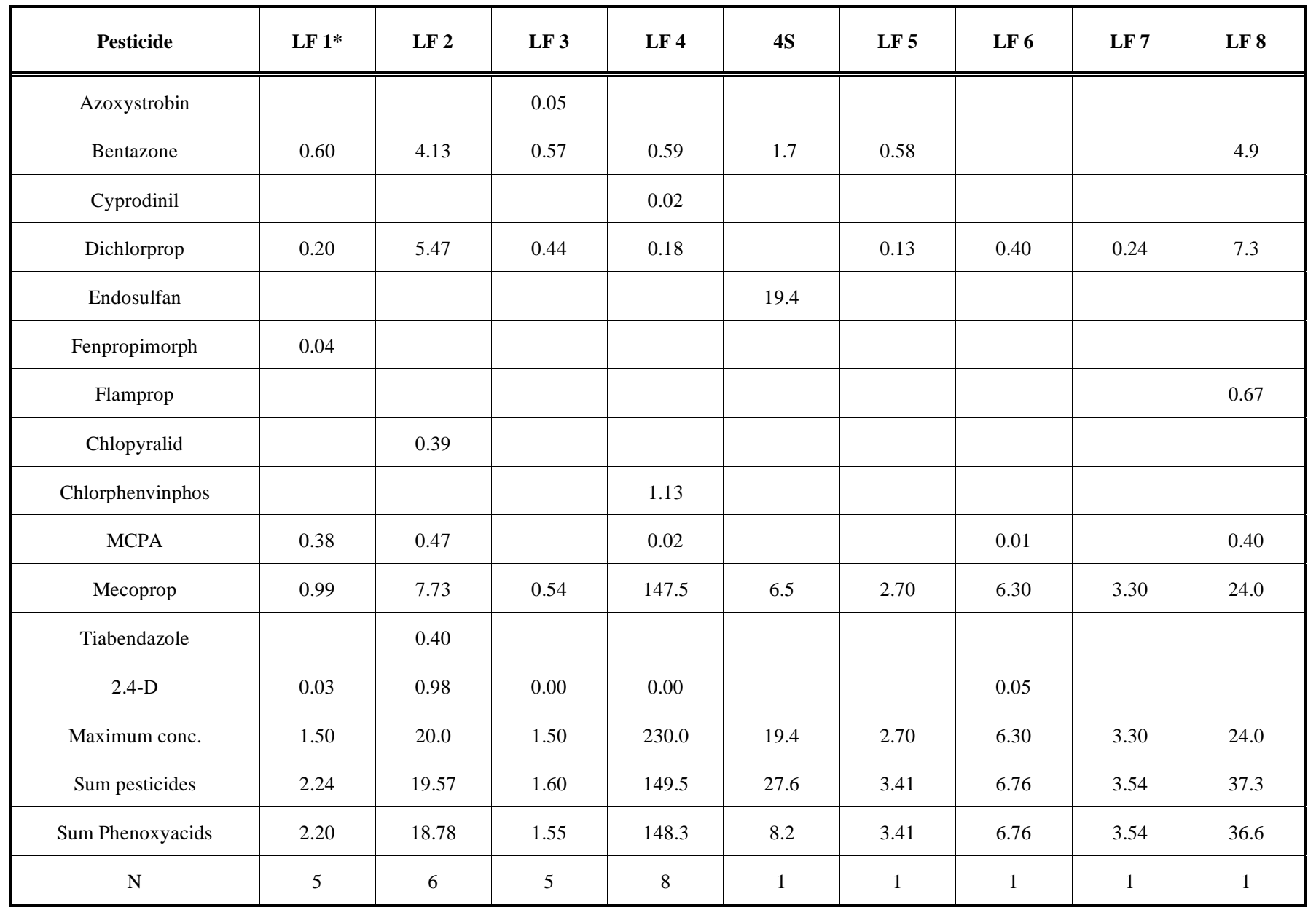

* LF1=landfill 1. 4S = leachate sediment from landfill 4 (in $\mathrm{mg} / \mathrm{kg}$ dry matter).

Landfill 1

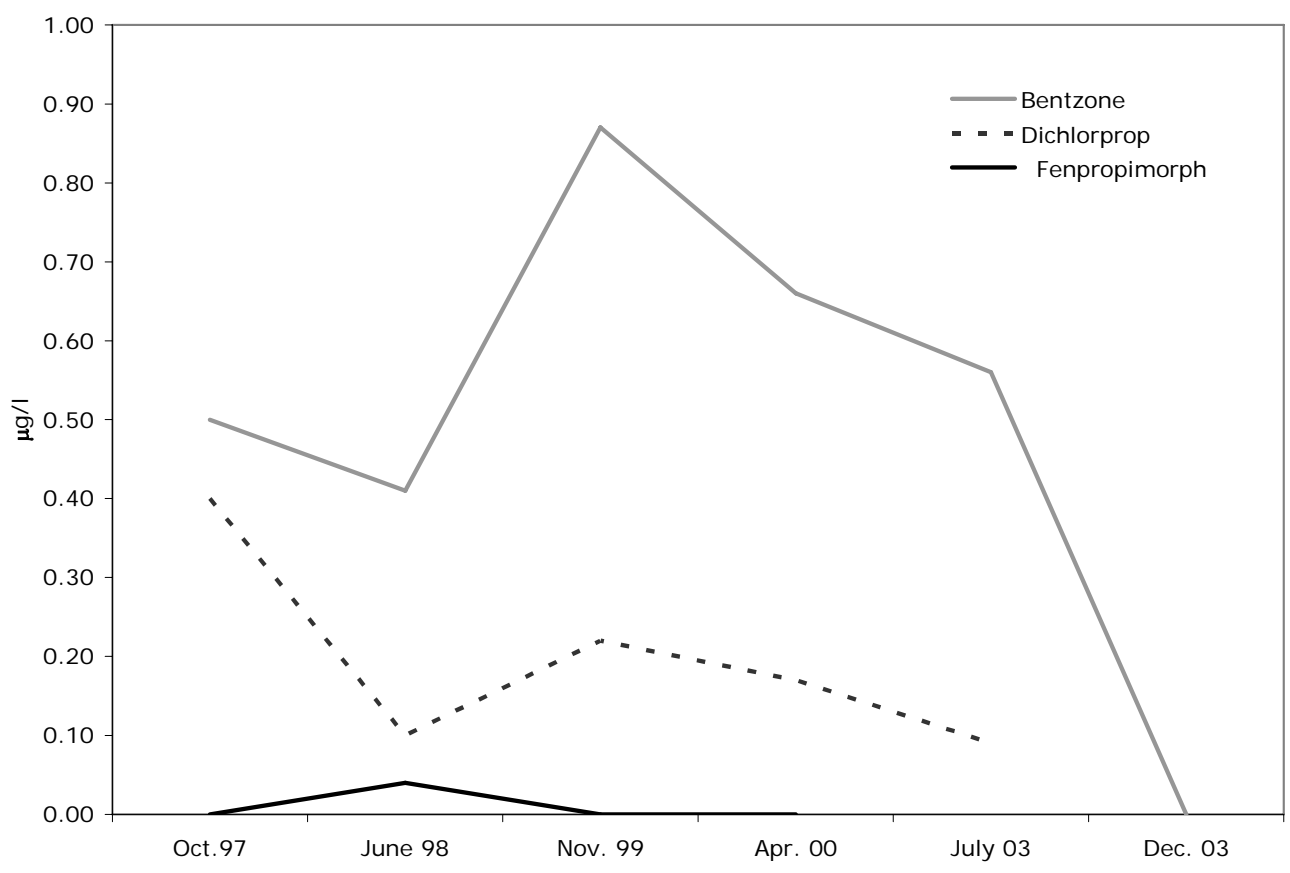




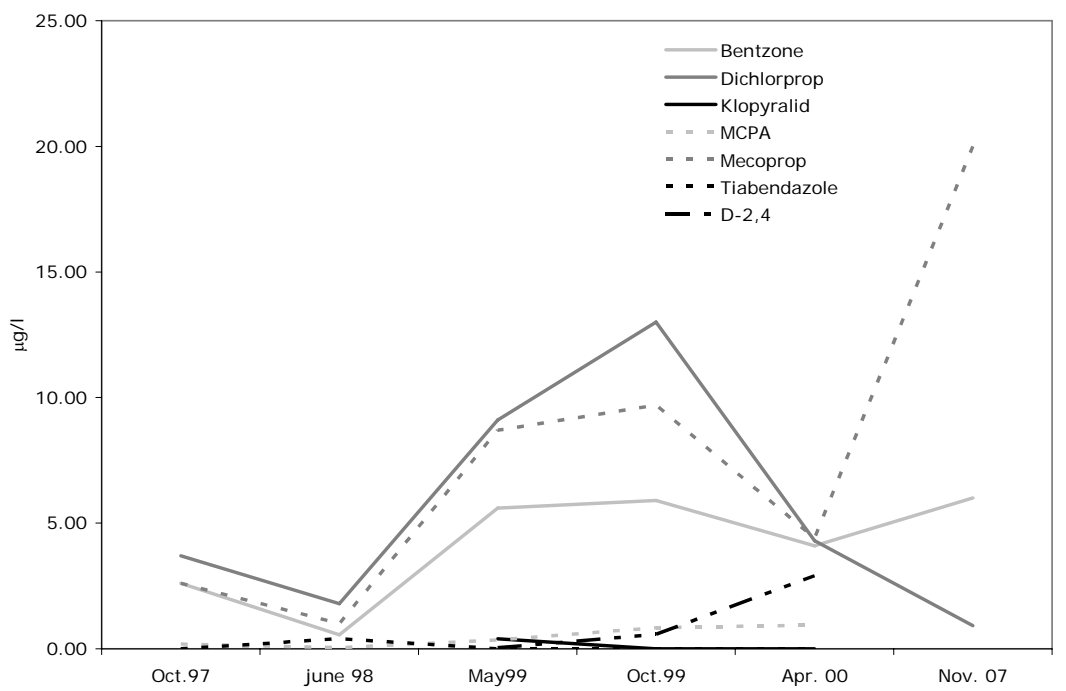

Landfill 3
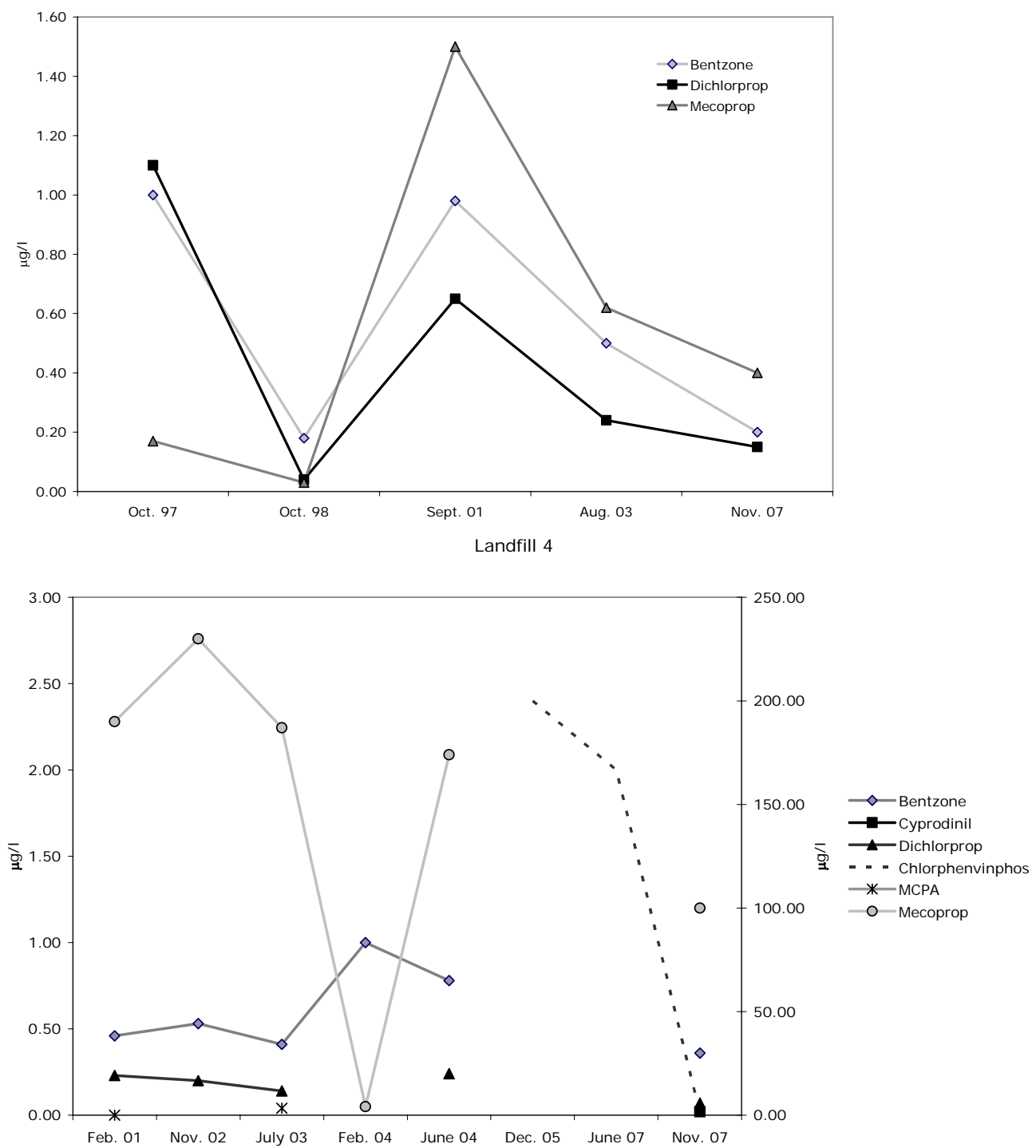

Fig. (1). Pesticide concentrations in landfills 1-4 (not in time-scale). For landfill 4, mecoprop is on the y-axis. 


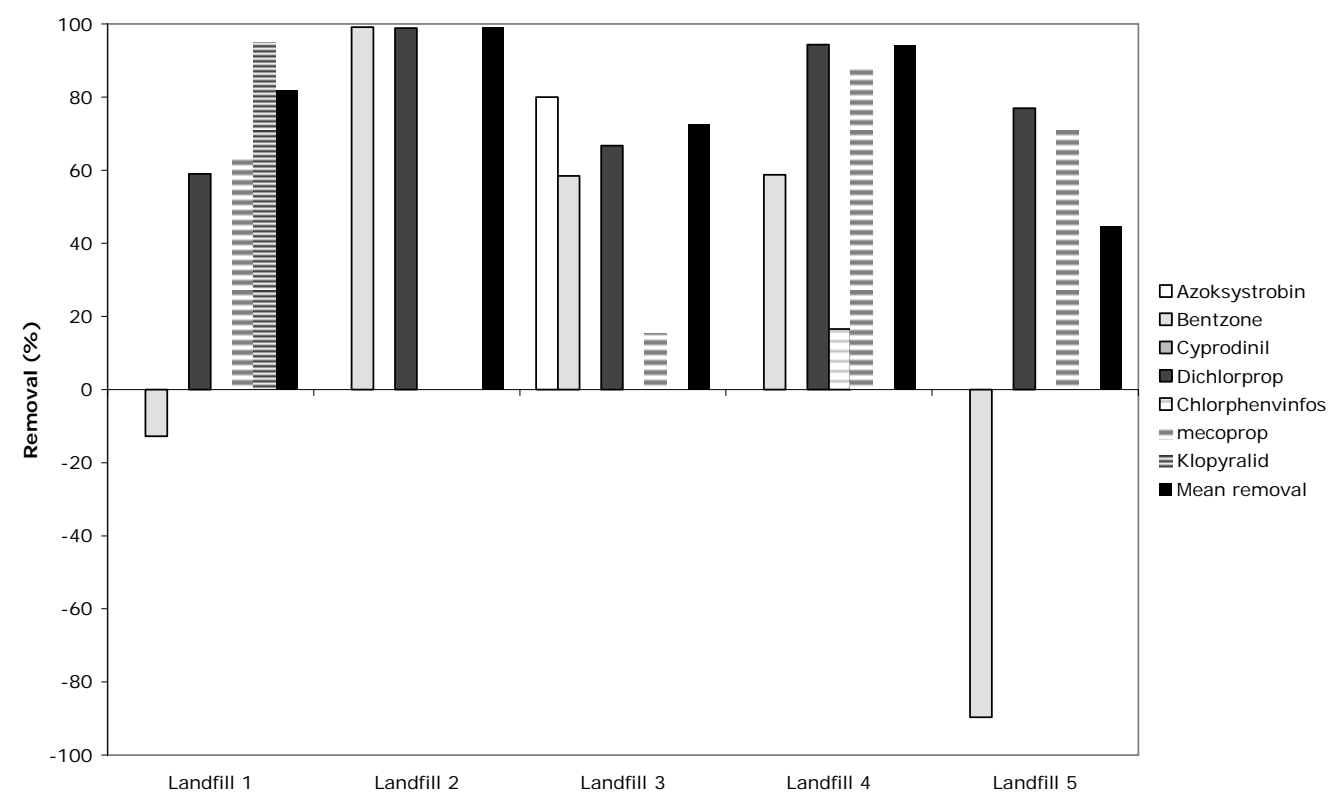

Fig. (2). Mean removal of pesticides in on-site treatment systems and number of samples from the treated leachate (Landfill $1=$ aeration, $n=3$; $2=$ reverse osmosis, $\mathrm{n}=1,3=$ natural attenuation+aeration $+\mathrm{CW}, \mathrm{n}=1 ; 4=$ aeration+biodam $+\mathrm{CW} n=7 ; 5=\mathrm{SBR}, \mathrm{n}=1$ ), see also Table 2 .

Table 5. Pesticide Emissions

\begin{tabular}{|c|c|c|c|}
\hline & Reverse Osmosis & Aeration /Wetlands & SBR \\
\hline \hline \multirow{3}{*}{ Pesticides detected after treatment } & & Phenoxy acids & Chlorphenvinphos \\
& & Isoproturon & Phenoxy acids \\
& Phenoxy acids & Chlopyralid & Mecoprop \\
\hline Concentration range $(\mu \mathrm{g} / \mathrm{l})$ & & $0.16-50$ & $0.03-1.1$ \\
\hline
\end{tabular}

tion and reactor treatment showed slightly lower removal. Phenoxy acids are prevalent in treated leachate, but in lower concentrations after treatment with reverse osmosis. In the wetland also an insecticide was found.

\section{ACKNOWLEDGEMENT}

The monitoring of environmental samples was sponsored by The Norwegian Pollution Control Authority (SFT). The detected compounds have low to high water solubility.

\section{REFERENCES}

[1] ECPA Statistical Review. European Crop Protection Association, Brussels, Belgium, 2002.

[2] Ludvigsen GH, Lode O. Trends of pesticides in Norwegian streams and rivers (1996-2000). Intern J of Anal Chem, Submitted.

[3] Haarstad K, Ludvigsen GH. Ten years of pesticide monitoring in Norwegian ground waters. Ground Water Monitoring \& Remediation 2007; 27(3): 75-89.

[4] Kjeldsen P, Barlaz MA, Rooker AP, Baun A, Ledin A, Christensen TH. Present and long-term composition of MSW landfill leachate: A review. Crit Rev Environ Sci Technol 2002; 32: 297-336.

[5] Baun A, Ledin A, Reitzel LA. Xenobiotic organic compounds in leachates from ten Danish MSW landfills-chemical analysis and toxicity tests. Water Res 2004; 38 (18): 3845-58.

[6] Tuxen N, Ejlskov P, Albrechtsen HJ, Reitzel LA, Pedersen JK, Bjerg PL. Application of natural attenuation to ground water con- taminated by phenoxy acid herbicides at an old landfill in Sjølund, Denmark. Ground Water Monitoring \& Remediation 2003; 23(4): 48-58.

[7] Robinson, HD, Barr, MJ. Aerobical biological treatment of landfill leachate. Waste Man Res 1999; 17: 478-86.

[8] SFT. Guidelines on Environmental Risk assessments of bottom liners and the collection of leachate at landfills. The Norwegian State Pollution Agency, Oslo, Report TA 1995, 1995.

[9] Haarstad K, Fresvig M. The Influence of Organic Matter and pH on DDT Aqueous Solubility. J Soil Contamination 2000; 9(4): 347 358.

[10] Holen B, Svensen A. Analysis of pesticides in water by gas chromatography. Norwegaion J Agricultural Sci 1994; 13: 211-2.

[11] Blankenberg AGB, Braskerud B, Haarstad K. Pesticide retention in two small constructed wetlands: treating non-point source pollution from agriculture runoff. Intern J Environ Anal Chem 2005; 86(3-4): 225-31.

[12] Braskerud, B, Haarstad, K. Screening the retention of thirteen pesticides in a small constructed wetland. Water Sci Technol 2003; 48(5): 267-74.

[13] Haarstad K, Braskerud B. Pesticide retention in the watershed and in a small constructed wetland treating diffuse pollution. Water Sci Technol 2005; 51(3-4): 143-50.

[14] Syversen N, Haarstad K. Retention of pesticides and nutrients in a vegetated buffer zone compared to soil with low biological activity. Intern J Environ Anal Chem 2005; 85(15): 1175-87.

[15] Tomlin C. The Pesticide Manual. Tenth Edition. The Royal Society of Chemistry, Cambridge, UK, 1994. 
[16] EXTOXNET. http://extoxnet.orst.edu/pips/ghindex.html, accessed February 1.2008.

[17] Wikipeda. http://en.wikipedia.org/wiki/Main_Page. Accessed February 1.2008 .
[18] Ludvigsen GH, Lode O. Summary of detected pesticides during 1995-2006. Results from the national soil and water monitoring program JOVA. Norwegian with English summary. Bioforsk Report 3(14), 2008. 